\title{
Effect of Operating Conditions on Catalytic Gasification of Bamboo in a Fluidized Bed
}

\author{
Thanasit Wongsiriamnuay, ${ }^{1}$ Nattakarn Kannang, ${ }^{2}$ and Nakorn Tippayawong ${ }^{2}$ \\ ${ }^{1}$ Division of Agricultural Engineering, Faculty of Engineering and Agro-Industry, Maejo University, Chiang Mai 50290, Thailand \\ ${ }^{2}$ Department of Mechanical Engineering, Faculty of Engineering, Chiang Mai University, Chiang Mai 50200, Thailand
}

Correspondence should be addressed to Thanasit Wongsiriamnuay; w_thanasit@hotmail.com

Received 19 March 2013; Revised 3 June 2013; Accepted 3 June 2013

Academic Editor: Deepak Kunzru

Copyright (c) 2013 Thanasit Wongsiriamnuay et al. This is an open access article distributed under the Creative Commons Attribution License, which permits unrestricted use, distribution, and reproduction in any medium, provided the original work is properly cited.

\begin{abstract}
Catalytic gasification of bamboo in a laboratory-scale, fluidized bed reactor was investigated. Experiments were performed to determine the effects of reactor temperature $\left(400,500\right.$, and $600^{\circ} \mathrm{C}$ ), gasifying medium (air and air/steam), and catalyst to biomass ratio $(0: 1,1: 1$, and $1.5: 1)$ on product gas composition, $\mathrm{H}_{2} / \mathrm{CO}$ ratio, carbon conversion efficiency, heating value, and tar conversion. From the results obtained, it was shown that at $400^{\circ} \mathrm{C}$ with air/steam gasification, maximum hydrogen content of $16.5 \% \mathrm{v} / \mathrm{v}$, carbon conversion efficiency of $98.5 \%$, and tar conversion of $80 \%$ were obtained. The presence of catalyst was found to promote the tar reforming reaction and resulted in improvement of heating value, carbon conversion efficiency, and gas yield due to increases in $\mathrm{H}_{2}, \mathrm{CO}$, and $\mathrm{CH}_{4}$. The presence of steam and dolomite had an effect on the increasing of tar conversion.
\end{abstract}

\section{Introduction}

Energy demand has been growing for the past several decades due to rapid industrial and urban development in industry, but fossil fuel reserves have been in decline [1]. Renewable energy has been very popular as an obvious candidate to substitute fossil fuels. Biomass is one of the renewable fuel sources that can claim to have significant environmental benefits with regards to neutral carbon emissions and reduction in global warming $[2,3]$. There are many biomass materials that can be utilized for energy [4]. Fast growing plants, which do not compete with food crops, may be used as sustainable energy resources $[5,6]$ for developed and developing countries. Biomass can be converted to biofuels via several pathways such as biochemical or thermochemical conversion. Gasification process is one of the promising technologies to produce syngas from solid feedstock [2, 7-9]. Producer gas containing simple molecular gas can be used, instead of fossil fuels, in combustion engines.

Gas production is dependent on input streams, operating conditions, and gas output conditioning. Input of gasification process is referred to by type and components of feedstock materials and type and flow of gasifying agent. Gas output conditioning is a process involved in cooling and disposing particulate matter and tar in the gas product. Gasification reactions are controlled by operation conditions such as temperature, pressure, and residence time. Reaction temperature is one of the most influential parameters for the gasification operation. Gasification temperature is normally classified into three ranges; low $\left(400-600^{\circ} \mathrm{C}\right)$, medium $\left(600-900^{\circ} \mathrm{C}\right)$, and high $\left(>900^{\circ} \mathrm{C}\right)$. Increasing temperature tends to result in increasing $\mathrm{H}_{2}, \mathrm{CO}$, gas heating value, carbon conversion efficiency, and gas yields. The advantage of gasification at low temperatures is due to reduced energy input, low tar yield [10], and low cost by partial oxidation, but heating value of fuel gas may be low. To increase the heating value of the product gas, steam may be added to the gasifying medium but additional energy input would be needed. This way, the $\mathrm{H}_{2}$ content in the producer gas can be improved. $\mathrm{H}_{2}$ has beneficial properties as a clean energy carrier for heat supply and transportation purposes $[2,8]$. Steam gasification takes place at high temperatures because the steam reforming reaction is an endothermic process, but catalytic steam gasification at low temperatures was more useful than high temperature 
with high content of $\mathrm{H}_{2}$ [10]. Chang et al. [11] found that maximum $\mathrm{H}_{2}$ content occurred at steam to biomass ratio of 1.

Normally, producer gas contains a high content of tar which can cause operational problems by blocking gas cooler, filter elements, and engine components. Most producer gas applications also require the removal of dust and tar before the gas can be used [12]. Tar can be effectively minimized in the producer gas by catalytic cracking. Many researchers have extensively studied and shown that a cheap additive such as calcined dolomite $(\mathrm{MgO}-\mathrm{CaO})$ was useful in reducing tar, improving gas quality and heating value for biomass gasification $[13,14]$. The destruction of tar is more effective at high temperatures, but increasing temperature may lead to higher tar yield [10]. At low temperature of $550^{\circ} \mathrm{C}$, Asadullah et al. [15] reported that, with the presence of dolomite, tar conversion was around $63 \%$. At medium temperature, Yu et al. [13] found that tar conversion of around $65-75 \%$ could be achieved at $700^{\circ} \mathrm{C}$, with the presence of dolomite. Increasing from 700 to $800^{\circ} \mathrm{C}$ resulted in a decrease in tar conversion. This was contributed to that fact that more stable compounds of tar were formed, so it was harder to crack. Chiang et al. [16] found that increasing content of $\mathrm{CaO}$ and temperature (600$900^{\circ} \mathrm{C}$ ) resulted in an increase of gas heating value and carbon conversion rate. At high temperatures, Akay and Jordan [17] used $\mathrm{CaO}$ as an in-bed catalyst in a fixed-bed gasifier at $1,040^{\circ} \mathrm{C}$ and obtained minimum tar yields of less than $0.8 \mathrm{~g} / \mathrm{kg}$ and maximum gas yield of $4 \mathrm{Nm}^{3} / \mathrm{kg}$. In addition, the gas produced can be applied into an internal combustion engine and gas burners fixed in the combustion chamber with the downstream process similar to the diesel burner [18].

Many reports exist in the open literature on gasification of various types of biomass, but studies on bamboo are rather limited. Bamboo is one of the fast growing and widely cultivated plants in many countries. It can be harvested within a few years [19]. So far, it has been used mainly as structural material for construction and household furniture [20-23]. Its utilization as renewable energy has not yet been investigated extensively. There have been several studies on thermal conversion of bamboo, but most work was about production of activated carbon [24-29], or bio-oil via pyrolysis [30-35]. Chiang et al. [16] investigated fixed-bed gasification of waste bamboo chopsticks. The heating value was found to be in the range of $2.0-10.6 \mathrm{MJ} / \mathrm{m}^{3}$, obtained between $600-900^{\circ} \mathrm{C}$ using $\mathrm{CaO}$ as a catalyst. Kantarelis et al. [5] used steam as a medium in the gasification of bamboo powder and reported that $10-20 \% \mathrm{H}_{2}$ and $15-20 \% \mathrm{CO}$ can be obtained between 797 and $865 \mathrm{~K}$. Increased steam to biomass ratio resulted in increased $\mathrm{H}_{2}, \mathrm{CO}_{2}$, and gas yield, but with reduction in $\mathrm{CO}$, $\mathrm{CH}_{4}$, and heating value. Gasification in a fluidized bed reactor was conducted by Xiao et al. [36] at $400-700^{\circ} \mathrm{C}$. The heating value was found to be $7.2 \mathrm{MJ} / \mathrm{Nm}^{3}$ at $700^{\circ} \mathrm{C}$ with excess air ratio of 0.2. Kannang et al. [37] found that the heating value was $5.26 \mathrm{MJ} / \mathrm{Nm}^{3}$ at $700 \mathrm{~K}$.

There appears to be a lack of information with respect to the gasification of bamboo in a fluidization reactor with the presence of a catalyst, especially at low temperature range. In this study, an experimental study in a fluidized bed
TABLE 1: Analysis of bamboo.

\begin{tabular}{lccc}
\hline Property & Unit & Method & Quantity \\
\hline Proximate analysis & & & \\
$\quad$ Moisture & $(\% \mathrm{w} / \mathrm{w})$ & ASTM D 3173 & 5.73 \\
Volatile & $(\% \mathrm{w} / \mathrm{w})$ & ASTM D 3175 & 74.68 \\
Fixed carbon & $(\% \mathrm{w} / \mathrm{w})$ & ASTM D 3172 & 14.04 \\
Ash & $(\% \mathrm{w} / \mathrm{w})$ & ASTM D 3177 & 5.55 \\
Ultimate analysis & & & \\
Carbon & $(\%)$ & ASTM D 3174 & 45.66 \\
Hydrogen & $(\%)$ & ASTM D 3174 & 4.32 \\
Nitrogen & $(\%)$ & ASTM D 3174 & 0.24 \\
Oxygen & $(\%)$ & By difference & 49.78 \\
LHV & $(\mathrm{MJ} / \mathrm{kg})$ & ASTM 5865 & 17.80 \\
C/O & & & 1.22 \\
H/O & & & 1.39 \\
\hline
\end{tabular}

reactor was conducted for the gasification of bamboo. The objective of this study was to investigate the effects of reactor temperature, gasifying medium, and catalyst to biomass ratio on composition of product, gas yield, heating value, and carbon conversion efficiency.

\section{Materials and Methods}

2.1. Biomass Materials and Catalysts. Samples of bamboo collected in Chiang Mai, Thailand, were used. The collected samples were dried, crushed, and ground in a high-speed rotary mill and sieved to provide a feed sample in the size range between 0.10 and $0.25 \mathrm{~mm}$. The moisture, volatile, fixed carbon, and ash were determined, following the ASTM standards. The carbon, hydrogen, and nitrogen contents were determined using a Thermo Scientific Instrument CHN elemental analyzer. The oxygen content was calculated by difference. The heating value of the dried bamboo was determined with a Parr bomb calorimeter. The analysis results of the bamboo samples are shown in Table 1 [37].

Silica sand with a particle size of 45 micron was used as inert bed material in the fluidized bed gasifier, while calcined dolomite was used as a catalyst. The dolomite was sieved to obtain a fraction with a particle size of 45 micron and then calcined in the oven at $900^{\circ} \mathrm{C}$ for $4 \mathrm{~h}$. The calcined dolomite was kept in a desiccator for later use.

2.2. Experimental Apparatus and Procedure. Figure 1 shows a schematic diagram of a fluidized bed gasification system used in this study. There are six main components. Air (1) and steam (2) supply units were composed of air and water supplies, control valves, flow meters, and preheaters. An external heating system (3) supplied heat at the bottom of the fluidized bed reactor. The fluidized bed reactor unit (4) comprised a biomass feeder and a reactor. The reactor was made from a stainless steel cylinder and was externally covered with a thick insulator. The total height of the reactor was $2 \mathrm{~m}$, with an internal diameter of $50 \mathrm{~mm}$. The reactor was installed with a series of thermocouples along the length in 


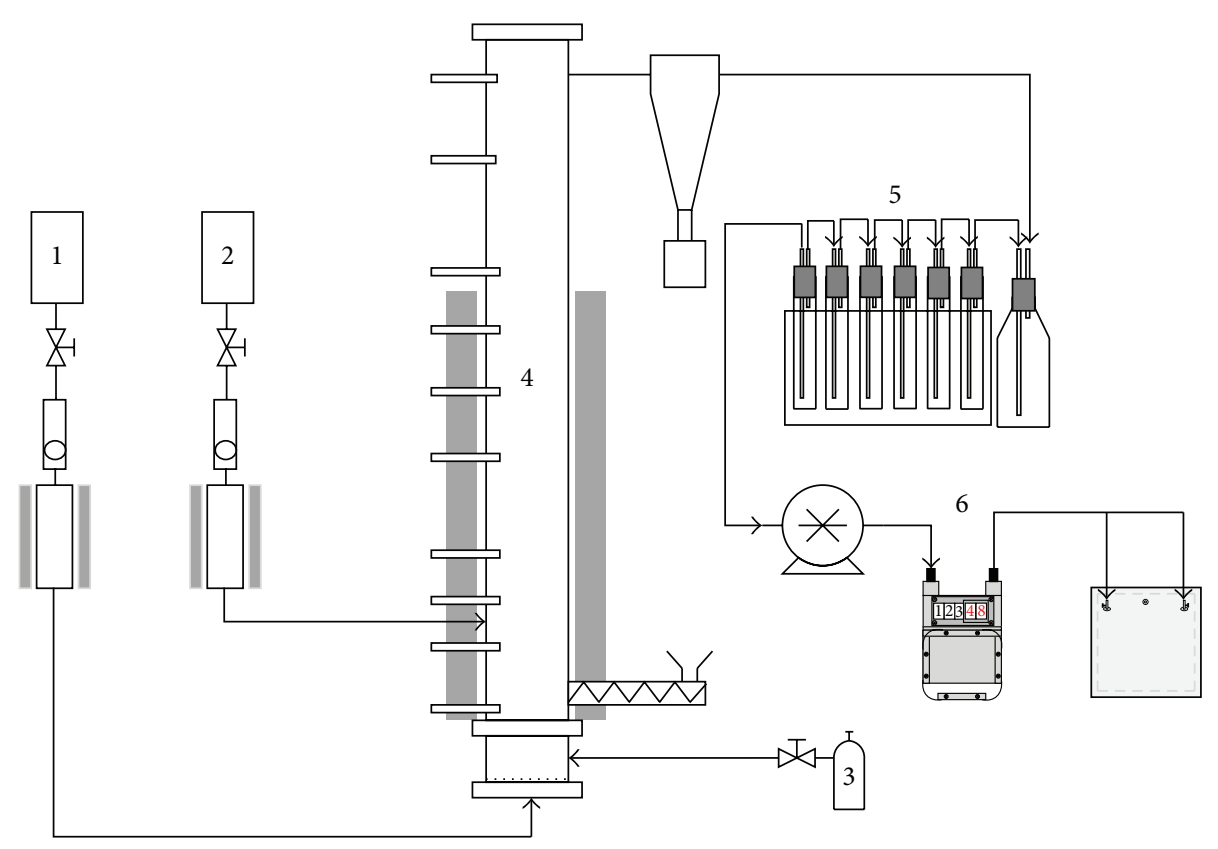

FIGURE 1: Schematic diagram of gasification reactor: (1) air supply, (2) steam supply, (3) external heating, (4) fluidized bed reactor, (5) gas conditioning, and (6) gas sampling unit.

order to measure the temperature distribution inside. An air distributor was installed to ensure uniform air distribution. A gas cleaning unit (5) consisted of a series of glass tubes containing isopropanol for gas cleaning and the collection of tar. The gas collecting unit (6) was constituted of a pump, a gas meter, and gas sampling bag. Cold fluidization tests in a transparent tube of the same dimension to the reactor were carried out for these biomass, dolomite, and silica sand particles between 5 and $30 \mathrm{l} / \mathrm{min}$ of air flows. It was visually confirmed that proper mixing was achieved at $151 / \mathrm{min}$ of air flow or higher.

The biomass was fed into the reactor. Air was used as the fluidizing agent and supplied from an air compressor at a constant flow rate of $15 \mathrm{l} / \mathrm{min}$ with the equivalent ratio (ER) of about 0.4 . Before the air entered the reactor, it was preheated to $300-500^{\circ} \mathrm{C}$. When steam was used, it was produced by a steam generator which fed steam to biomass $(\mathrm{S} / \mathrm{B})$ ratio of $1: 1$ at $150^{\circ} \mathrm{C}$ into the reactor. Biomass was continuously fed into the reactor by the screw feeder from the hopper at a constant rate of $10 \mathrm{~g} / \mathrm{min}$.

Each run was started by filling the bed with silica sand, with or without dolomite up to the desired catalyst to biomass $(\mathrm{C} / \mathrm{B})$ ratio between $0: 1,1: 1$, and $1.5: 1 \mathrm{w} / \mathrm{w}$. The burner was then turned on to provide heat externally. The startup period was necessary to preheat the bed. After the bed temperature reached the desired level and became steady, the air compressor was turned on to drive the air through the preheater, air distributor, and into the reactor before the commencement of the biomass feeding. The product gas exited the reactor through a cyclone, via gas conditioning unit, and gas sampling system. Char was separated from the producer gas in the cyclone. The produced gas passed through an ice trap for cooling and cleaning. The dry and clean gas was sampled using gas bags and analyzed by gas chromatography. The Shimadzu GC model GC-8A fitted with a Shin-carbon column, and TCD detector was used to detect $\mathrm{H}_{2}, \mathrm{O}_{2}, \mathrm{~N}_{2}, \mathrm{CH}_{4}, \mathrm{CO}$, and $\mathrm{CO}$. The gas chromatograph was calibrated using standard gases. Helium was used as a carrier gas. Tar was condensed and collected in a series of glass tubes containing isopropanol and it was measured by gravimetric method. The collected tar contained primary and condensed tertiary that dilute in a solvent [38]. Each experimental test's conditions were repeated at least three times. Average values were subsequently presented with error bar.

From the data collected, lower heating value (LHV) and carbon conversion efficiency (CCE) were calculated from the following equations [39]:

$$
\begin{aligned}
& \mathrm{LHV}=\left(30 \mathrm{CO} \%+25.7 \mathrm{H}_{2} \%+85.4 \mathrm{CH}_{4} \%\right) \times 4.2\left(\frac{\mathrm{kJ}}{\mathrm{Nm}^{3}}\right), \\
& \mathrm{CCE}=\frac{V_{\mathrm{g}} / 22.4 \times\left[\mathrm{CH}_{4} \%+\mathrm{CO} \%+\mathrm{CO}_{2} \%\right]}{W(1-\mathrm{ash}) \times \mathrm{C} \% / 12} \times 100 \%,
\end{aligned}
$$

where $\mathrm{CO}, \mathrm{CO}_{2}, \mathrm{H}_{2}$, and $\mathrm{CH}_{4}$ are the concentrations of the gas products, $V_{\mathrm{g}}$ is the gas yield measured from the gas meter, and $W, \mathrm{C} \%$, and ash are referred to as the biomass feeding rate, carbon, and ash contents in the biomass, respectively.

\section{Results and Discussion}

3.1. Effects of Temperature and Gasifying Medium. The effects of temperature and gasifying medium on the gas content with nitrogen-free are shown in Figure 2. The reactor temperature was varied between 400 and $600^{\circ} \mathrm{C}$. Precision of temperature was about $\pm 20^{\circ} \mathrm{C}$ for all experiments. Increasing temperature 

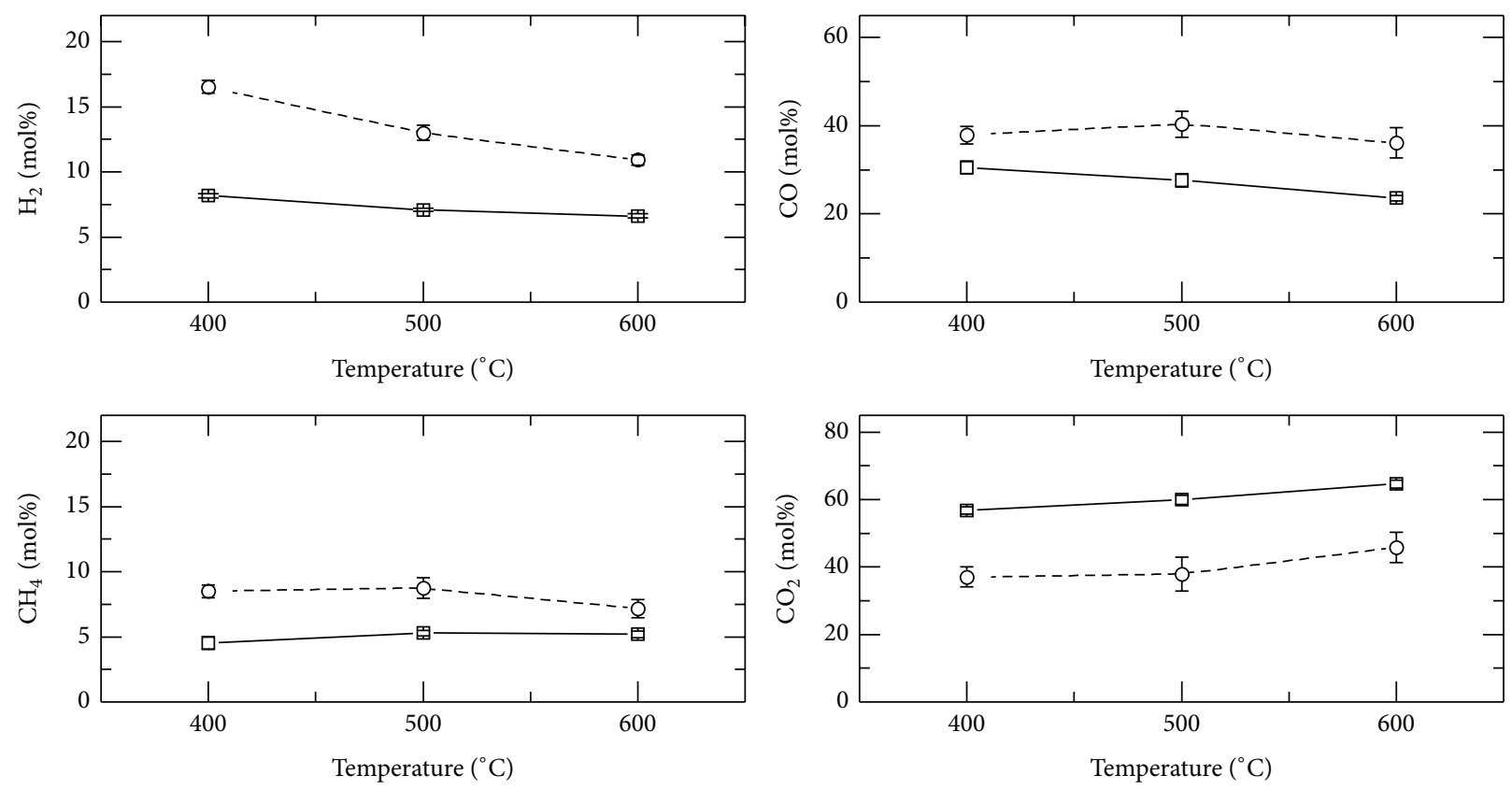

$-\square-$ Air
$-0-$ Air-steam

$\rightarrow-$ Air

-O- Air-steam

FIGURE 2: Effect of gasifying medium on gas composition at different temperatures.

from 400 to $600^{\circ} \mathrm{C}$ was found to decrease $\mathrm{H}_{2}$ and $\mathrm{CO}$ contents by around $1.5-5.6 \%$ and $4.2-6.9 \%$, respectively. CO content decreased with increasing temperature due to the endothermic reaction [37], while $\mathrm{CO}_{2}$ increased by around $7.8-8.7 \%$ with increasing temperature from 400 to $600^{\circ} \mathrm{C}$. $\mathrm{CH}_{4}$ decreased with increasing temperature from 400 to $600^{\circ} \mathrm{C}$ due to the reaction of steam and $\mathrm{CH}_{4}[10]$.

$\mathrm{H}_{2}$, CO, and $\mathrm{CH}_{4}$ contents in the product gas were higher when an air/steam mixture was used as the gasifying medium. But $\mathrm{CO}_{2}$ content from air gasification was higher than that from air-steam gasification [40]. With air gasification, an increased degree of combustion rate may occur to release more $\mathrm{CO}_{2}$ due to the higher $\mathrm{ER}(0.4)$ used in the gasification process. Combustion reactions hardly produce $\mathrm{H}_{2}$ [41]. It was reported that $\mathrm{H}_{2}$ content in product gas was obtained from the dehydrogenation of biomass components and secondary decomposition of their pyrolyzed products (reactions (2) or (3)) $[37,41]$ :

$$
\begin{aligned}
\text { Biomass } \longrightarrow & \mathrm{H}_{2}+\mathrm{CO}+\mathrm{CO}_{2}+\mathrm{CH}_{4} \\
& +\mathrm{C}_{n} \mathrm{H}_{m}+\mathrm{N}_{2}+\text { Tars }+ \text { Ash } \\
\mathrm{C}_{n} \mathrm{H}_{m} \mathrm{O}_{z} \longrightarrow & a \mathrm{CO}_{2}+b \mathrm{H}_{2} \mathrm{O}+c \mathrm{CH}_{4} \\
& +d \mathrm{CO}+e \mathrm{H}_{2}+f\left(\mathrm{C}_{2}-\mathrm{C}_{5}\right)
\end{aligned}
$$

$\mathrm{H}_{2}$ and $\mathrm{CO}$ were decreased at higher temperatures [4] due to the high reactivity of char with air at a higher ER. Increasing temperature favors the endothermic reaction; hence $\mathrm{CO}$ content decreased due to a more complete oxidation reaction (reaction (4)) and partial oxidation reaction (reaction (5)) which resulted in increasing $\mathrm{CO}_{2}$ [4]. Skoulou et al. [42] suggested that the reaction of char combustion was composed of absorption and desorption. $\mathrm{O}_{2}$ was absorbed by $\mathrm{C}$ which represented carbon active site and released $\mathrm{C}(\mathrm{O})$ which was a carbon-oxygen complex in reaction (6). Subsequently, $\mathrm{CO}_{2}$ was released by desorption (reactions (7) and (8)). Oxygen from $\mathrm{CO}_{2}$ was absorbed by char to form $\mathrm{C}(\mathrm{O})$ and released $\mathrm{CO}$ (reaction (9)). CO was desorbed from surface oxygen complex from reaction (10) and absorbed and reacted with $\mathrm{C}(\mathrm{O})$ in reaction (11) and released $\mathrm{CO}_{2}[42,43]$ :

$$
\begin{aligned}
\mathrm{C}+\mathrm{O}_{2} & \longleftrightarrow \mathrm{CO}_{2} \\
\mathrm{C}+\frac{1}{2} \mathrm{O}_{2} & \longleftrightarrow \mathrm{CO} \\
2 \mathrm{C}+\mathrm{O}_{2} & \longleftrightarrow 2 \mathrm{C}(\mathrm{O}) \\
2 \mathrm{C}(\mathrm{O}) & \longleftrightarrow \mathrm{CO}_{2} \\
\mathrm{C}(\mathrm{O})+2 \mathrm{C}(\mathrm{O}) & \longleftrightarrow \mathrm{CO}_{2}+\mathrm{C} \\
\mathrm{C}+\mathrm{CO} 2 & \longleftrightarrow \mathrm{C}(\mathrm{O})+\mathrm{CO} \\
\mathrm{C}(\mathrm{O}) & \longleftrightarrow \mathrm{C}+\mathrm{CO} \\
\mathrm{C}(\mathrm{O})+\mathrm{CO} & \longleftrightarrow \mathrm{C}+\mathrm{CO}_{2}
\end{aligned}
$$

Figure 3 shows that increasing temperature affected LHV due to the reduction in $\mathrm{H}_{2}$ and $\mathrm{CO}$ content [44]. Carbon conversion efficiency was found to increase due to an increase in $\mathrm{CO}_{2}$ content while gas yields remained constant. LHV, carbon conversion efficiency, and gas yield were found to increase when air/steam was used as agent in the gasification 

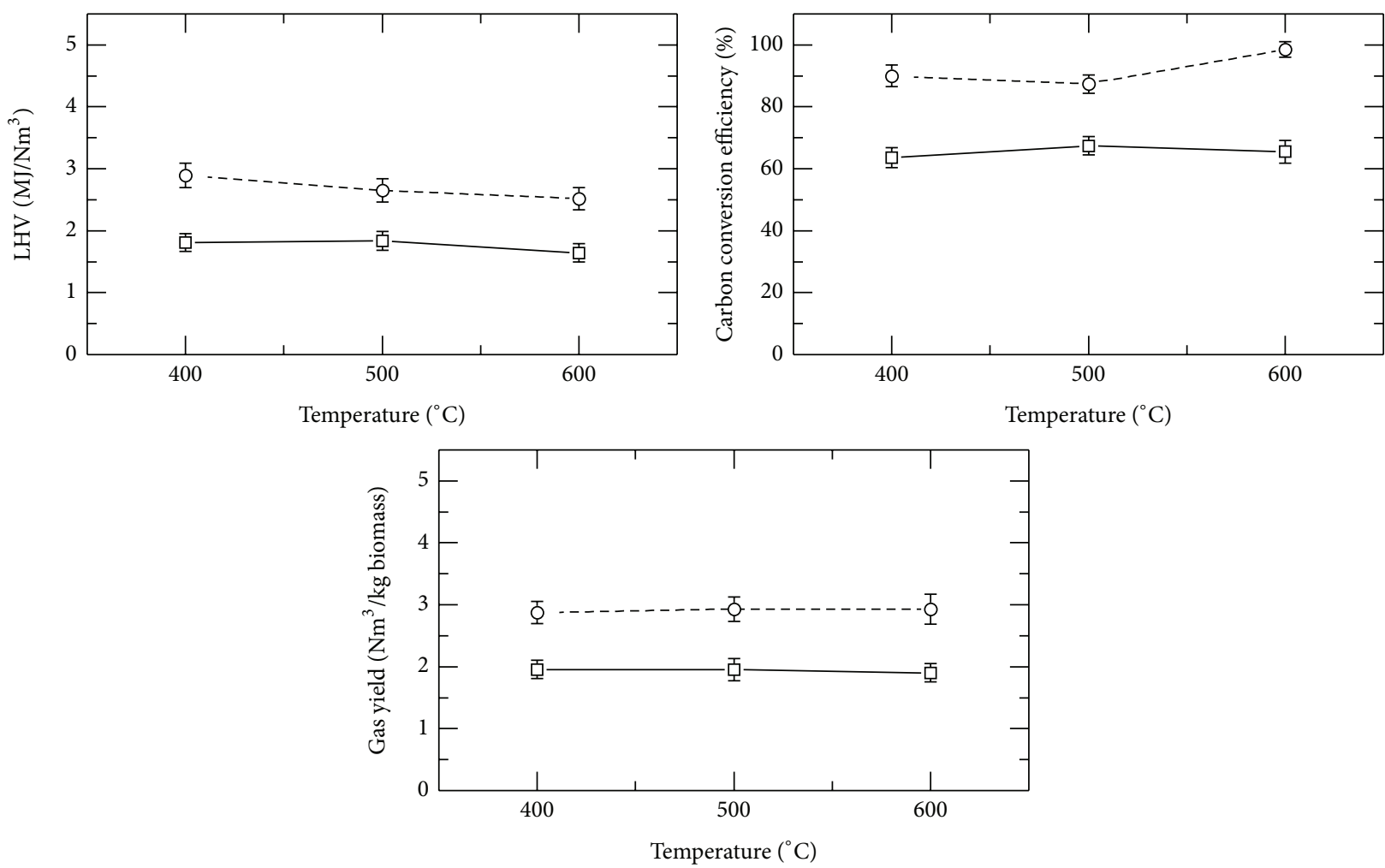

$\neg \square$ Air

-O- Air-steam

FIGURE 3: Effect of gasifying medium on LHV, carbon conversion efficiency, and gas yield at different temperatures.

process. This was so because higher contents of $\mathrm{H}_{2}, \mathrm{CO}$, and $\mathrm{CH}_{4}$ were expected from the water-gas reaction [39].

3.2. Effect of Catalyst to Biomass Ratio. The effects of catalyst on gas compositions with nitrogen-free are shown in Figure 4. It was found that the content of $\mathrm{H}_{2}$ and $\mathrm{CO}$ increased, while the content of $\mathrm{CH}_{4}$ and $\mathrm{CO}_{2}$ slightly decreased with increasing temperature and catalyst to biomass ratio [10]. It was reported that tar cracking and tar reforming reactions resulted in increased content of $\mathrm{H}_{2}$ at higher temperatures, according to reactions (12)-(14) $[9,48-$ 50]. The content of $\mathrm{CO}_{2}$ increased initially with increasing temperature and then decreased when temperatures were higher than $500^{\circ} \mathrm{C}$. With increased catalyst to biomass ratio from 0 to 1.5 , higher content of $\mathrm{CO}_{2}$ was obtained due to the release of $\mathrm{CO}_{2}$ from dolomite. At higher temperatures, reforming of tar with $\mathrm{CO}_{2}$ with the presence of dolomite led to a decrease of $\mathrm{CO}_{2}$. The reforming reaction of tar on a dolomite surface occurred by capturing carbon to produce more $\mathrm{H}_{2}$ and $\mathrm{CO}$, according to reaction (14) [50]:

$$
\begin{gathered}
\mathrm{C}_{n} \mathrm{H}_{m} \longleftrightarrow n \mathrm{C}+\left(\frac{m}{2}\right) \mathrm{H}_{2} \\
\mathrm{C}_{n} \mathrm{H}_{m}+n \mathrm{H}_{2} \mathrm{O} \stackrel{\text { Dolomite }}{\longleftrightarrow} n \mathrm{CO}+\left(n+\frac{m}{2}\right) \mathrm{H}_{2} \\
\mathrm{C}_{n} \mathrm{H}_{m}+n \mathrm{CO}_{2} \stackrel{\text { Dolomite }}{\longleftrightarrow} 2 n \mathrm{CO}+\left(\frac{m}{2}\right) \mathrm{H}_{2}
\end{gathered}
$$

$$
\begin{gathered}
\mathrm{C}+\mathrm{CO}_{2} \longleftrightarrow 2 \mathrm{CO} \\
\mathrm{C}_{n} \mathrm{H}_{x} \mathrm{O}_{z}+\mathrm{CO}_{2} \longleftrightarrow \mathrm{CO}+\mathrm{H}_{2} \mathrm{O}+\text { Tar endothermic. }
\end{gathered}
$$

At high temperatures, increase in $\mathrm{CO}$ and decrease in $\mathrm{CO}_{2}$ contents were due to reactions (15) and (16). $\mathrm{CO}_{2}$ reacted with excess carbon in char, producing $\mathrm{CO}$ (reaction (15)) similar to those previously reported $[41,46]$. The reforming of $\mathrm{CO}_{2}$ with tar (reaction (16)) produced $\mathrm{CO}$ and $\mathrm{H}_{2} \mathrm{O}$. The presence of catalyst promoted the tar reforming reaction, leading to a decrease in tar yield. From Figure 5, it was clear that increasing temperature and catalyst amount resulted in improvement of LHV, carbon conversion efficiency, and gas yield due to the increase in $\mathrm{H}_{2}, \mathrm{CO}$, and $\mathrm{CH}_{4}$ contents.

From Figure 6, it was found that tar conversion increased with increasing temperature for all cases. With air-steam gasification, tar conversion was increased from 84 to $92 \%$ and 77 to $90 \%$ when catalyst to biomass ratio was increased from $1: 1$ to $1.5: 1$, respectively. The trend was similar to those previously reported $[13,15]$.

3.3. Comparison with the Literature. Table 2 shows producer gas composition, gas ratio and yields, carbon conversion efficiency from different biomass materials, and reactor configurations found from the reported literature. In the comparison of bamboo with other agricultural residues [45, 47], it was found that the $\mathrm{H}_{2}$ content obtained was in 

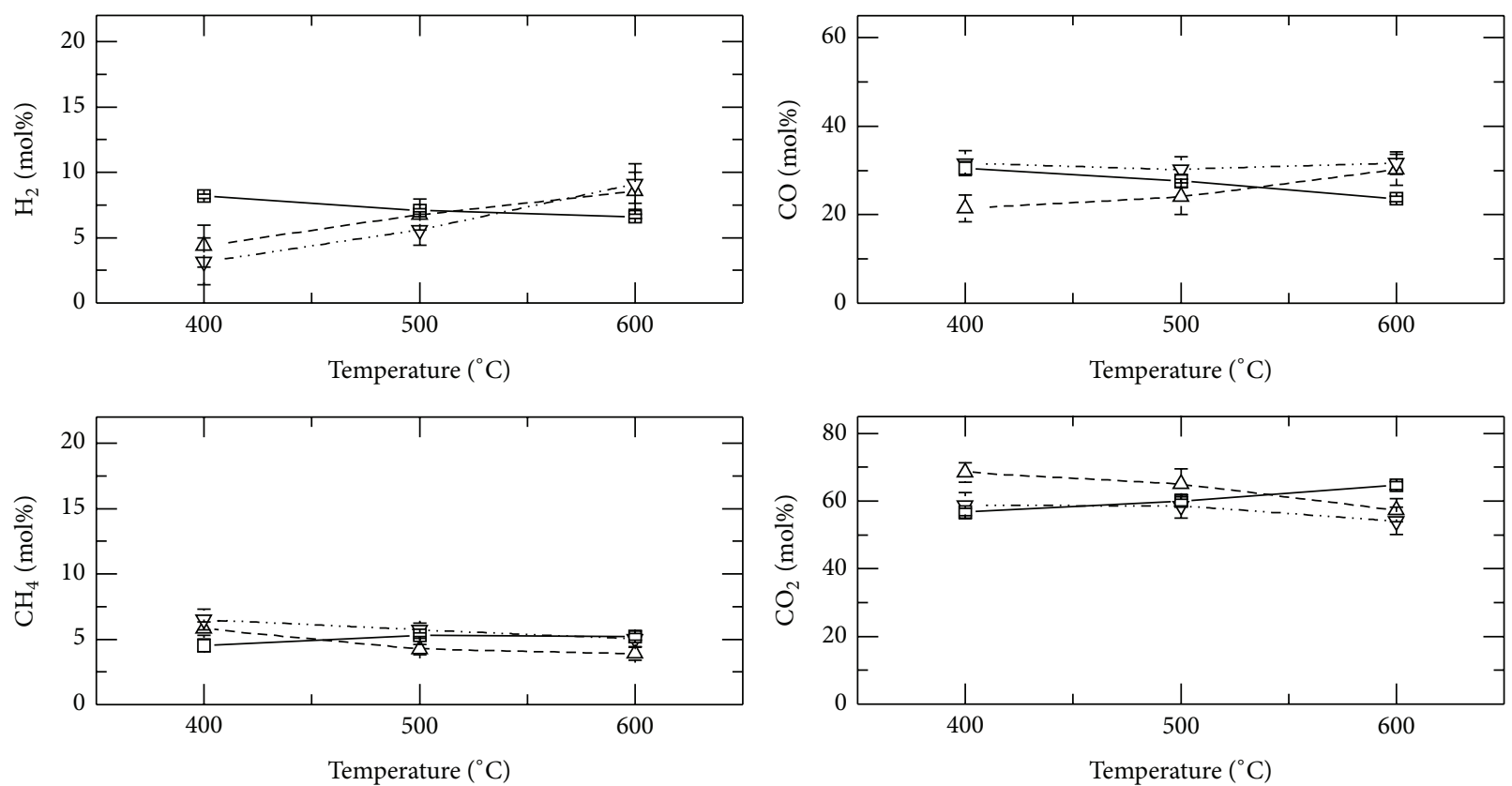

$\neg-\mathrm{C}: \mathrm{B} 0$

$-\triangle-C: B 1$

$\therefore \nabla \cdot \mathrm{C}: \mathrm{B} 1.5$

$\neg-\mathrm{C}: \mathrm{B} 0$

$-\triangle-C: B 1$

$\therefore \cdot \mathrm{C}: \mathrm{B} 1.5$

Figure 4: Effect of catalyst ratio on gas composition at different temperatures.
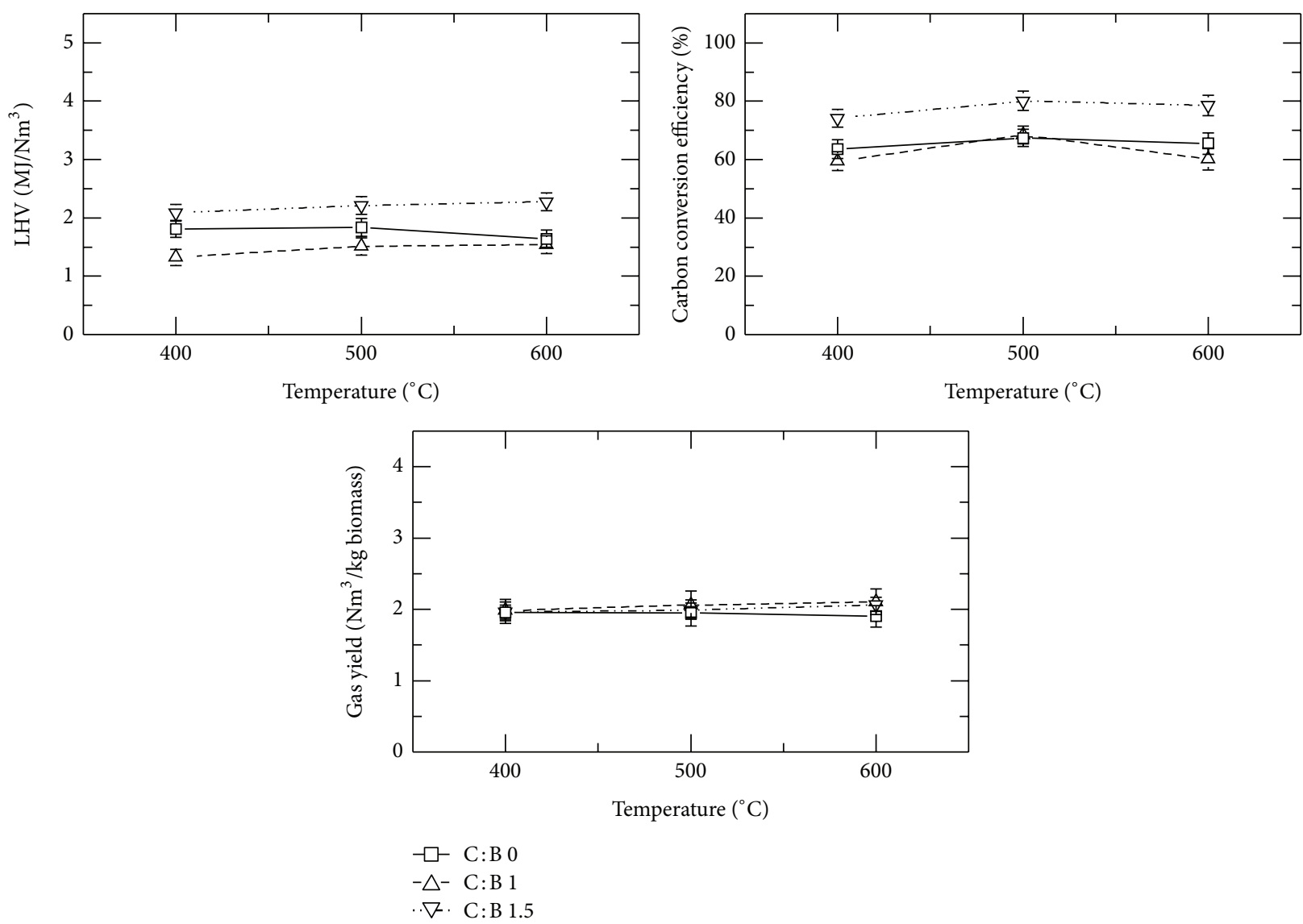

FIGURE 5: Effect of catalyst ratio on LHV, carbon conversion efficiency, and gas yield at different temperatures. 
TABLE 2: Comparison with the existing literature.

\begin{tabular}{|c|c|c|c|c|c|c|c|c|c|c|c|}
\hline \multirow{2}{*}{ Ref } & \multirow{2}{*}{ Biomass } & \multirow{2}{*}{$C: B$} & \multirow{2}{*}{ S/B } & \multirow{2}{*}{ Agent } & \multirow{2}{*}{ ER } & \multirow{2}{*}{$T\left({ }^{\circ} \mathrm{C}\right)$} & \multicolumn{2}{|c|}{$(\% \mathrm{~mol})$} & \multirow{2}{*}{$\mathrm{H}_{2} / \mathrm{CO}$} & \multirow{2}{*}{$\begin{array}{l}\text { Gas yield } \\
\left(\mathrm{Nm}^{3} / \mathrm{kg}\right)\end{array}$} & \multirow{2}{*}{ CCE (\%) } \\
\hline & & & & & & & $\mathrm{H}_{2}$ & $\mathrm{CO}$ & & & \\
\hline \multirow{3}{*}{ This work } & \multirow{3}{*}{ Bamboo } & - & . & \multirow{2}{*}{ Air } & \multirow{3}{*}{0.4} & \multirow{3}{*}{$400-600$} & $6.6-8.16$ & $23.5-30.6$ & $0.25-0.28$ & $1.9-2.0$ & $63.6-67.4$ \\
\hline & & $1: 1-1: 1.5$ & - & & & & $3.2-9.1$ & $21.4-31.7$ & $0.1-0.3$ & $1.9-2.1$ & $59.5-80.1$ \\
\hline & & - & $1: 1$ & Air-steam & & & $10.9-16.5$ & $36.1-40.3$ & $0.3-0.4$ & $2.8-2.9$ & $87.3-98.5$ \\
\hline$[1]$ & Pine sawdust & $3 \%$ & $0.75-0.9$ & Air-steam & $0.22-0.3$ & 800 & $35.87-40.67$ & $22.71-29.88$ & $1.2-1.79$ & $1.5-2.3$ & - \\
\hline$[45]$ & Rice husk & - & - & Air & $0.25-0.35$ & $665-1103$ & $4.0-3.3$ & $19.9-12.3$ & $0.20-0.26$ & $1.3-1.9$ & $55-81$ \\
\hline \multirow{2}{*}[46]{} & \multirow{2}{*}{ Sewage sludge } & $10,15 \%$ & - & Air & \multirow{2}{*}{0.3} & $750-850$ & $9.9-15.2$ & $6.1-14.4$ & $1.05-1.62$ & $2.5-2.8$ & $69.9-88.6$ \\
\hline & & $10 \%$ & $0.5,1$ & Air-steam & & 800 & $15.7-16.8$ & $7.5-9.1$ & $1.7-2.2$ & $2.7-2.8$ & $82.5-83.0$ \\
\hline \multirow[t]{2}{*}{ [39] } & Pine sawdust & - & $2.81: 1$ & Air-steam & 0.22 & $700-900$ & $21.0-38.0$ & $33.0-43.0$ & $0.5-1.2$ & $1.4-2.5$ & $78.2-92.6$ \\
\hline & Coir pith & & & & & & $5.6-10.6$ & $6.5-12.7$ & $0.7-1.0$ & $1.9-3.2$ & - \\
\hline \multirow[t]{2}{*}{ [47] } & Rice husk & - & - & Air & $0.3-0.5$ & $400-900$ & $5.3-8.6$ & $9.3-19.6$ & $0.4-0.67$ & $1.8-2.8$ & - \\
\hline & Saw dust & & & & & & $5.2-10.1$ & $10.78-16.84$ & $0.41-0.58$ & $2.2-3.7$ & - \\
\hline \multirow{2}{*}{ [11] } & \multirow{2}{*}{ Cellulose } & \multirow{2}{*}{ - } & - & Air & 0.2 & $600-1000$ & $5.29-9.5$ & $12.13-23.6$ & $0.44-1.46$ & $0.3-1.2$ & $12.13-23.6$ \\
\hline & & & $0-1.5$ & Air-steam & 0.27 & 800 & $13.5-18.6$ & $6.4-11.2$ & $1.2-2.2$ & $0.8-1.0$ & - \\
\hline
\end{tabular}

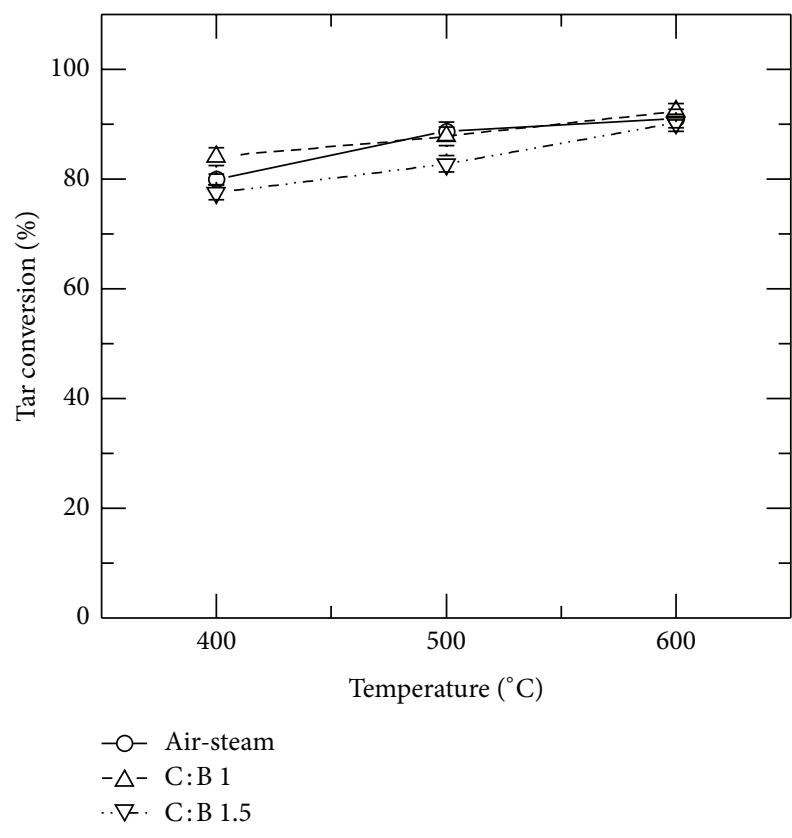

FIGURE 6: Effect of steam and catalyst ratio on tar conversion at different temperatures.

similar magnitude, but $\mathrm{CO}$ appeared to be higher than other biomass materials. The $\mathrm{H}_{2}$ content obtained from air/steam gasification of bamboo was lower than that from pine sawdust but was in a similar range to those from cellulose and sewage sludge. Regarding the CO content, bamboo was similar to pine sawdust but higher than cellulose and sewage sludge $[1,11,39,46]$. As far as catalytic gasification was concerned, $\mathrm{H}_{2}$ from bamboo showed a similar magnitude to that from sewage sludge but was lower than pine sawdust $[1,46]$. $\mathrm{H}_{2} / \mathrm{CO}$ was found to be lower than those from the literature. Gas yields and carbon conversion efficiency obtained from bamboo gasification were similar to other biomass materials but higher than cellulose.

\section{Conclusions}

In this study, the investigation of low-temperature gasification of bamboo in a fluidized bed reactor has been carried out. The effects of temperature, gasifying medium, and catalyst to biomass ratio on gas composition, LHV, and carbon conversion efficiency of fuel gas were evaluated. The results showed that the content of $\mathrm{H}_{2}$ and $\mathrm{CO}$ in the fuel gas decreased with increasing temperature while the content of $\mathrm{CO}_{2}$ increased. Added steam was found to enhance the quality of fuel gas, showing higher contents of $\mathrm{H}_{2}, \mathrm{CO}$, and LHV. The presence of a catalyst was found to increase the amount of $\mathrm{H}_{2}$ and $\mathrm{CO}$ in fuel gas at higher temperature, whereas the opposite trends were true for $\mathrm{CO}_{2}$.

\section{Acknowledgments}

The authors would like to acknowledge the support from the Thailand Research Fund (Contract no. RSA5080010) and the National Research Council of Thailand. Dr. Suphatz Sukamolson was thanked for assistance in preparing the manuscript.

\section{References}

[1] P. Lv, J. Chang, T. Wang, Y. Fu, Y. Chen, and J. Zhu, "Hydrogenrich gas production from biomass catalytic gasification," Energy and Fuels, vol. 18, no. 1, pp. 228-233, 2004.

[2] L. Wei, S. Xu, L. Zhang, C. Liu, H. Zhu, and S. Liu, "Steam gasification of biomass for hydrogen-rich gas in a free-fall reactor," International Journal of Hydrogen Energy, vol. 32, no. 1, pp. 24-31, 2007.

[3] S. Panigrahi, A. K. Dalai, S. T. Chaudhari, and N. N. Bakhshi, "Synthesis gas production from steam gasification of biomassderived oil," Energy and Fuels, vol. 17, no. 3, pp. 637-642, 2003. 
[4] M. K. Ko, W.-Y. Lee, S.-B. Kim, K.-W. Lee, and H.-S. Chun, "Gasification of food waste with steam in fluidized bed," The Korean Journal of Chemical Engineering, vol. 18, no. 6, pp. 961964, 2001.

[5] E. Kantarelis, J. Liu, W. Yang, and W. Blasiak, "Sustainable valorization of bamboo via high-temperature steam pyrolysis for energy production and added value materials," Energy and Fuels, vol. 24, no. 11, pp. 6142-6150, 2010.

[6] T. Wongsiriamnuay and N. Tippayawong, "Thermogravimetric analysis of giant sensitive plants under air atmosphere," Bioresource Technology, vol. 101, no. 23, pp. 9314-9320, 2010.

[7] B. Acharya, A. Dutta, and P. Basu, "An investigation into steam gasification of biomass for hydrogen enriched gas production in presence of CaO," International Journal of Hydrogen Energy, vol. 35, no. 4, pp. 1582-1589, 2010.

[8] J. Li, Y. Yin, X. Zhang, J. Liu, and R. Yan, "Hydrogen-rich gas production by steam gasification of palm oil wastes over supported tri-metallic catalyst," International Journal of Hydrogen Energy, vol. 34, no. 22, pp. 9108-9115, 2009.

[9] T. Wongsiriamnuay and N. Tippayawong, "Product gas distribution and composition from catalyzed gasification of mimosa," International Journal of Renewable Energy Research, vol. 2, no. 3, pp. 363-368, 2012.

[10] B. Moghtaderi, "Effects of controlling parameters on production of hydrogen by catalytic steam gasification of biomass at low temperatures," Fuel, vol. 86, no. 15, pp. 2422-2430, 2007.

[11] A. C. C. Chang, H.-F. Chang, F.-J. Lin, K.-H. Lin, and C.H. Chen, "Biomass gasification for hydrogen production," International Journal of Hydrogen Energy, vol. 36, no. 21, pp. 14252-14260, 2011.

[12] C. Li and K. Suzuki, "Tar property, analysis, reforming mechanism and model for biomass gasification-An overview," Renewable and Sustainable Energy Reviews, vol. 13, no. 3, pp. 594-604, 2009.

[13] Q.-Z. Yu, C. Brage, T. Nordgreen, and K. Sjöström, "Effects of Chinese dolomites on tar cracking in gasification of birch," Fuel, vol. 88, no. 10, pp. 1922-1926, 2009.

[14] A. K. Dalai, E. Sasaoka, H. Hikita, and D. Ferdoust, "Catalytic gasification of sawdust derived from various biomass," Energy and Fuels, vol. 17, no. 6, pp. 1456-1463, 2003.

[15] M. Asadullah, S.-I. Ito, K. Kunimori, M. Yamada, and K. Tomishige, "Biomass gasification to hydrogen and syngas at low temperature: novel catalytic system using fluidized-bed reactor," Journal of Catalysis, vol. 208, no. 2, pp. 255-259, 2002.

[16] K.-Y. Chiang, Y.-S. Chen, W.-S. Tsai, C.-H. Lu, and K.-L. Chien, "Effect of calcium based catalyst on production of synthesis gas in gasification of waste bamboo chopsticks," International Journal of Hydrogen Energy, vol. 37, no. 18, pp. 13737-13745, 2012.

[17] G. Akay and C. A. Jordan, "Gasification of fuel cane bagasse in a downdraft gasifier: influence of lignocellulosic composition and fuel particle size on syngas composition and yield," Energy and Fuels, vol. 25, no. 5, pp. 2274-2283, 2011.

[18] S. Dasappa, H. V. Sridhar, G. Sridhar, P. J. Paul, and H. S. Mukunda, "Biomass gasification-a substitute to fossil fuel for heat application," Biomass and Bioenergy, vol. 25, no. 6, pp. 637649, 2003.

[19] G. Xiao, M.-J. Ni, H. Huang et al., "Fluidized-bed pyrolysis of waste bamboo," Journal of Zhejiang University A, vol. 8, no. 9, pp. 1495-1499, 2007.

[20] W. K. Yu, K. F. Chung, and S. L. Chan, "Axial buckling of bamboo columns in bamboo scaffolds," Engineering Structures, vol. 27, no. 1, pp. 61-73, 2005.
[21] Y. Li, H. Shen, W. Shan, and T. Han, "Flexural behavior of lightweight bamboosteel composite slabs," Thin-Walled Structures, vol. 53, pp. 83-90, 2012.

[22] T. Y. Lo, H. Z. Cui, P. W. C. Tang, and H. C. Leung, "Strength analysis of bamboo by microscopic investigation of bamboo fibre," Construction and Building Materials, vol. 22, no. 7, pp. 1532-1535, 2008.

[23] K. Ghavami, "Bamboo as reinforcement in structural concrete elements," Cement and Concrete Composites, vol. 27, no. 6, pp. 637-649, 2005.

[24] W. H. Cheung, S. S. Y. Lau, S. Y. Leung, A. W. M. Ip, and G. McKay, "Characteristics of chemical modified activated carbons from bamboo scaffolding," The Chinese Journal of Chemical Engineering, vol. 20, no. 3, pp. 515-523, 2012.

[25] K. K. H. Choy, J. P. Barford, and G. McKay, "Production of activated carbon from bamboo scaffolding waste-process design, evaluation and sensitivity analysis," Chemical Engineering Journal, vol. 109, no. 1, pp. 147-165, 2005.

[26] A. W. M. Ip, J. P. Barford, and G. McKay, "Production and comparison of high surface area bamboo derived active carbons," Bioresource Technology, vol. 99, no. 18, pp. 8909-8916, 2008.

[27] Q.-S. Liu, T. Zheng, P. Wang, and L. Guo, "Preparation and characterization of activated carbon from bamboo by microwaveinduced phosphoric acid activation," Industrial Crops and Products, vol. 31, no. 2, pp. 233-238, 2010.

[28] S.-F. Lo, S.-Y. Wang, M.-J. Tsai, and L.-D. Lin, "Adsorption capacity and removal efficiency of heavy metal ions by Moso and Ma bamboo activated carbons," Chemical Engineering Research and Design, vol. 90, no. 9, pp. 1397-1406, 2011.

[29] E. L. K. Mui, W. H. Cheung, M. Valix, and G. Mckay, "Activated carbons from bamboo scaffolding using acid activation," Separation and Purification Technology, vol. 74, no. 2, pp. 213-218, 2010.

[30] Z. Jiang, Z. Liu, B. Fei, Z. Cai, Y. Yu, and X. Liu, "The pyrolysis characteristics of moso bamboo," Journal of Analytical and Applied Pyrolysis, vol. 94, pp. 48-52, 2012.

[31] S.-H. Jung, B.-S. Kang, and J.-S. Kim, "Production of bio-oil from rice straw and bamboo sawdust under various reaction conditions in a fast pyrolysis plant equipped with a fluidized bed and a char separation system," Journal of Analytical and Applied Pyrolysis, vol. 82, no. 2, pp. 240-247, 2008.

[32] M. Krzesińska and J. Zachariasz, “The effect of pyrolysis temperature on the physical properties of monolithic carbons derived from solid iron bamboo," Journal of Analytical and Applied Pyrolysis, vol. 80, no. 1, pp. 209-215, 2007.

[33] R. Lou, S.-B. Wu, and G.-J. Lv, "Effect of conditions on fast pyrolysis of bamboo lignin," Journal of Analytical and Applied Pyrolysis, vol. 89, no. 2, pp. 191-196, 2010.

[34] E. L. K. Mui, W. H. Cheung, V. K. C. Lee, and G. McKay, "Compensation effect during the pyrolysis of tyres and bamboo," Waste Management, vol. 30, no. 5, pp. 821-830, 2010.

[35] K. Umeki, T. Namioka, and K. Yoshikawa, “The effect of steam on pyrolysis and char reactions behavior during rice straw gasification," Fuel Processing Technology, vol. 94, no. 1, pp. 5360, 2012.

[36] G. Xiao, Y. Chi, M. Ni, and K. Cen, "Study on fluidized-bed gasification of bamboo," Acta Energiae Solaris Sinica, vol. 28, no. 7, pp. 814-818, 2007.

[37] N. Kannang, T. Wongsiriamnuay, and N. Tippayawong, "Fuel gas production from low temperature gasification of bamboo in 
fluidized bed reactor," in Proceedings of the International conference of the Thai Society of Agricultural Engineering, Chiangmai, Thailand., 2012.

[38] G. Gautam, S. Adhikari, S. Thangalazhy-Gopakumar, C. Brodbeck, S. Bhavnani, and S. Taylor, "Tar analysis in syngas derived from pelletized biomass in a commercial stratified downdraft gasifier," BioResources, vol. 6, no. 4, pp. 4652-4661, 2011.

[39] P. M. Lv, Z. H. Xiong, J. Chang, C. Z. Wu, Y. Chen, and J. X. Zhu, "An experimental study on biomass air-steam gasification in a fluidized bed," Bioresource Technology, vol. 95, no. 1, pp. 95-101, 2004.

[40] S. H. Lee, K. B. Choi, J. G. Lee, and J. H. Kim, "Gasification characteristics of combustible wastes in a 5 ton/day fixed bed gasifier," The Korean Journal of Chemical Engineering, vol. 23, no. 4, pp. 576-580, 2006.

[41] Y. Zhang, S. Kajitani, M. Ashizawa, and Y. Oki, "Tar destruction and coke formation during rapid pyrolysis and gasification of biomass in a drop-tube furnace," Fuel, vol. 89, no. 2, pp. 302309, 2010.

[42] V. Skoulou, G. Koufodimos, Z. Samaras, and A. Zabaniotou, "Low temperature gasification of olive kernels in a $5-\mathrm{kW}$ fluidized bed reactor for $\mathrm{H}_{2}$-rich producer gas," International Journal of Hydrogen Energy, vol. 33, no. 22, pp. 6515-6524, 2008.

[43] A. Montoya, T.-T. T. Truong, F. Mondragón, and T. N. Truong, "CO desorption from oxygen species on carbonaceous surface: 1. Effects of the local structure of the active site and the surface coverage," Journal of Physical Chemistry A, vol. 105, no. 27, pp. 6757-6764, 2001

[44] H.-K. Seo, S. Park, J. Lee et al., "Effects of operating factors in the coal gasification reaction," The Korean Journal of Chemical Engineering, vol. 28, no. 9, pp. 1851-1858, 2011.

[45] K. G. Mansaray, A. E. Ghaly, A. M. Al-Taweel, F. Hamdullahpur, and V. I. Ugursal, "Air gasification of rice husk in a dual distributor type fluidized bed gasifier," Biomass and Bioenergy, vol. 17, no. 4, pp. 315-332, 1999.

[46] J. M. de Andrés, A. Narros, and M. E. Rodríguez, "Behaviour of dolomite, olivine and alumina as primary catalysts in air-steam gasification of sewage sludge," Fuel, vol. 90, no. 2, pp. 521-527, 2011.

[47] P. Subramanian, A. Sampathrajan, and P. Venkatachalam, "Fluidized bed gasification of select granular biomaterials," Bioresource Technology, vol. 102, no. 2, pp. 1914-1920, 2011.

[48] I. Narváez, A. Orío, M. P. Aznar, and J. Corella, "Biomass gasification with air in an atmospheric bubbling fluidized bed. Effect of six operational variables on the quality of the produced raw gas," Industrial and Engineering Chemistry Research, vol. 35, no. 7, pp. 2110-2120, 1996.

[49] T.-Y. Mun, P.-G. Seon, and J.-S. Kim, "Production of a producer gas from woody waste via air gasification using activated carbon and a two-stage gasifier and characterization of tar," Fuel, vol. 89, no. 11, pp. 3226-3234, 2010.

[50] P. Basu, Biomass Gasification and Pyrolysis: Practical Design and Theory, Academic Press, Boston, Mass, USA, 2010. 

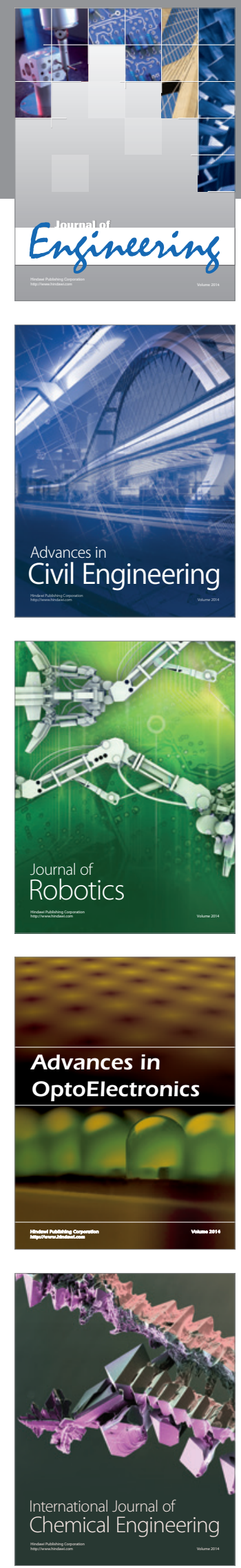

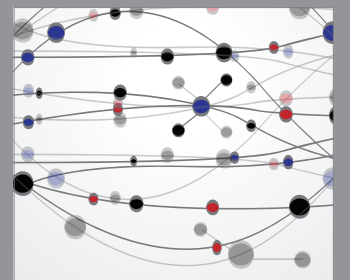

The Scientific World Journal
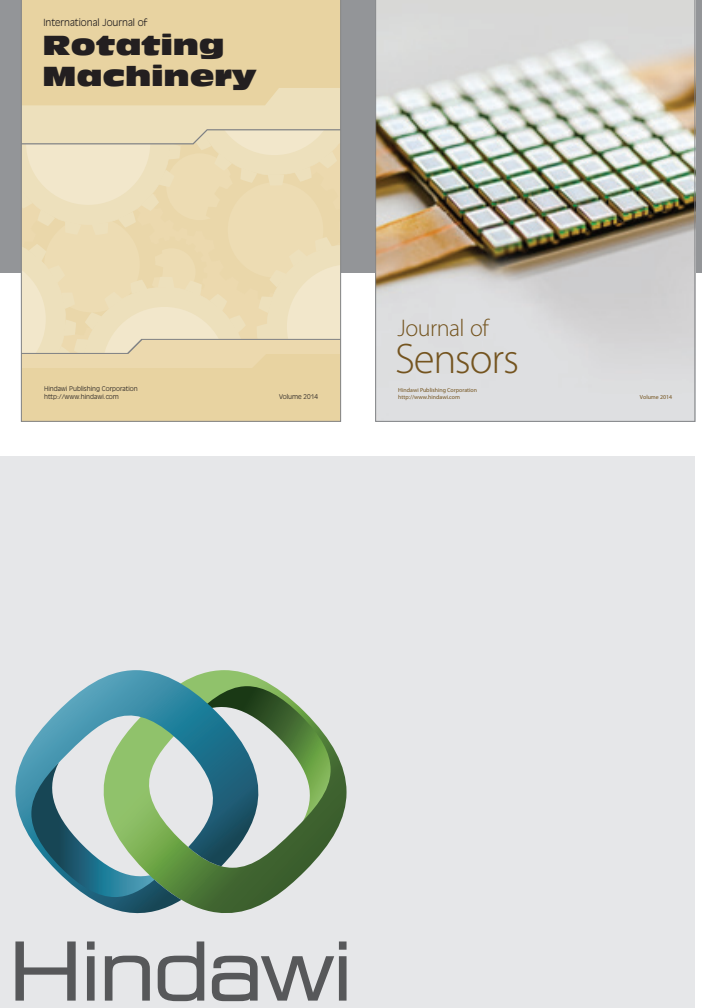

Submit your manuscripts at http://www.hindawi.com
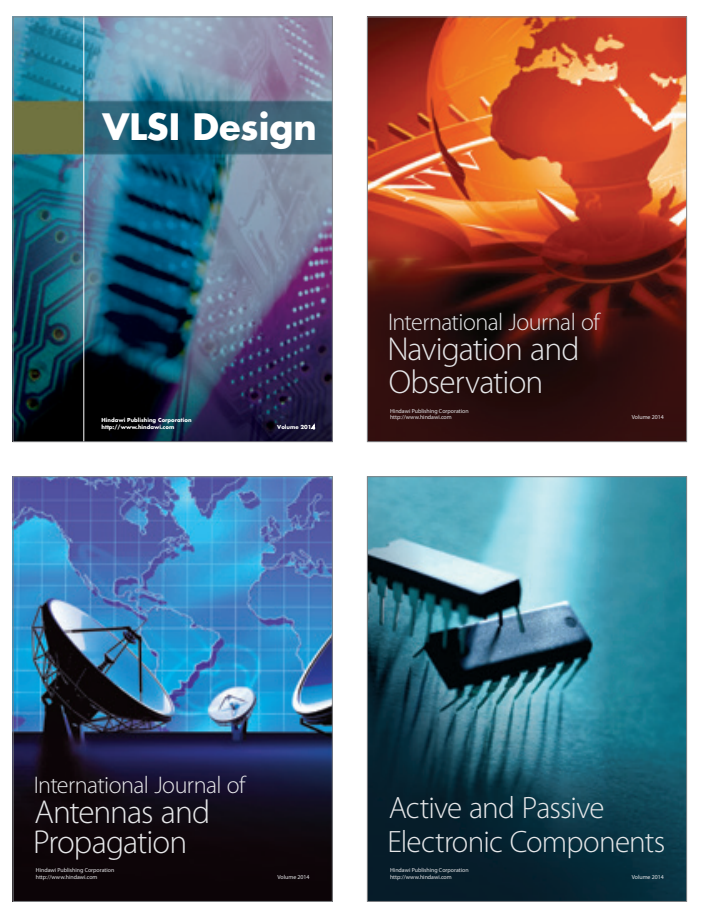
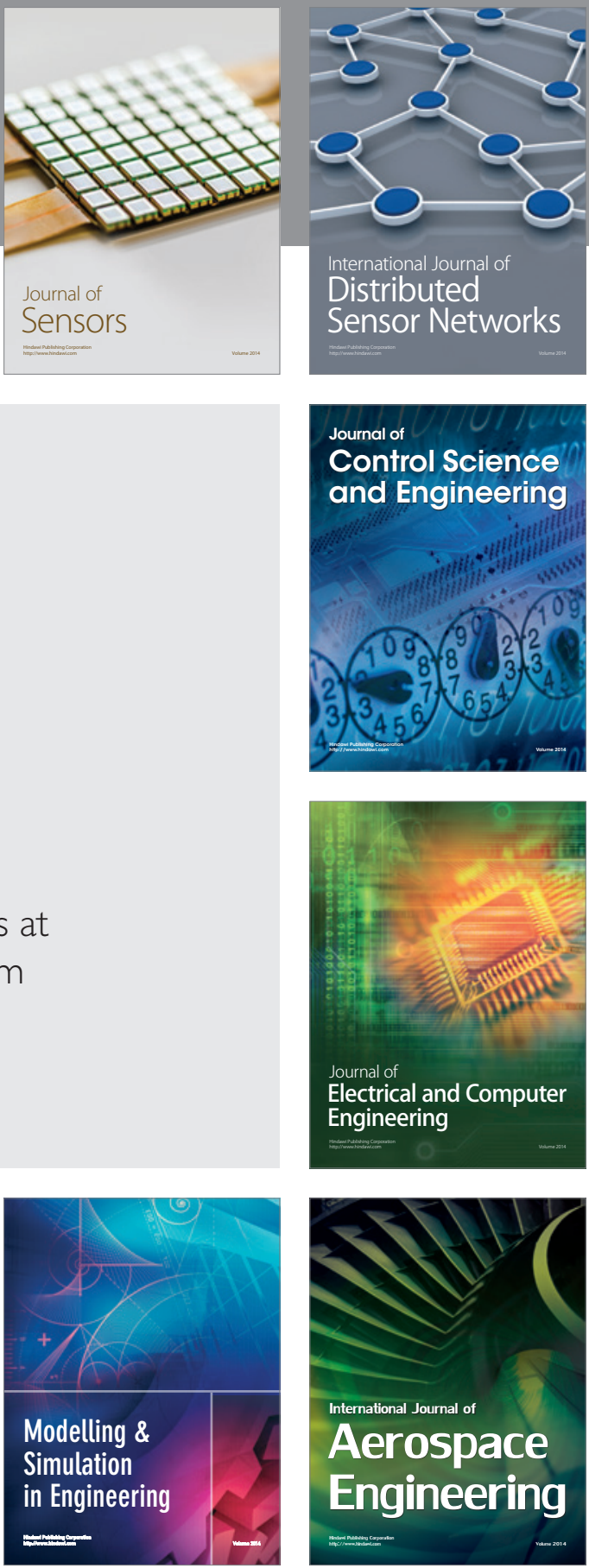

Journal of

Control Science

and Engineering
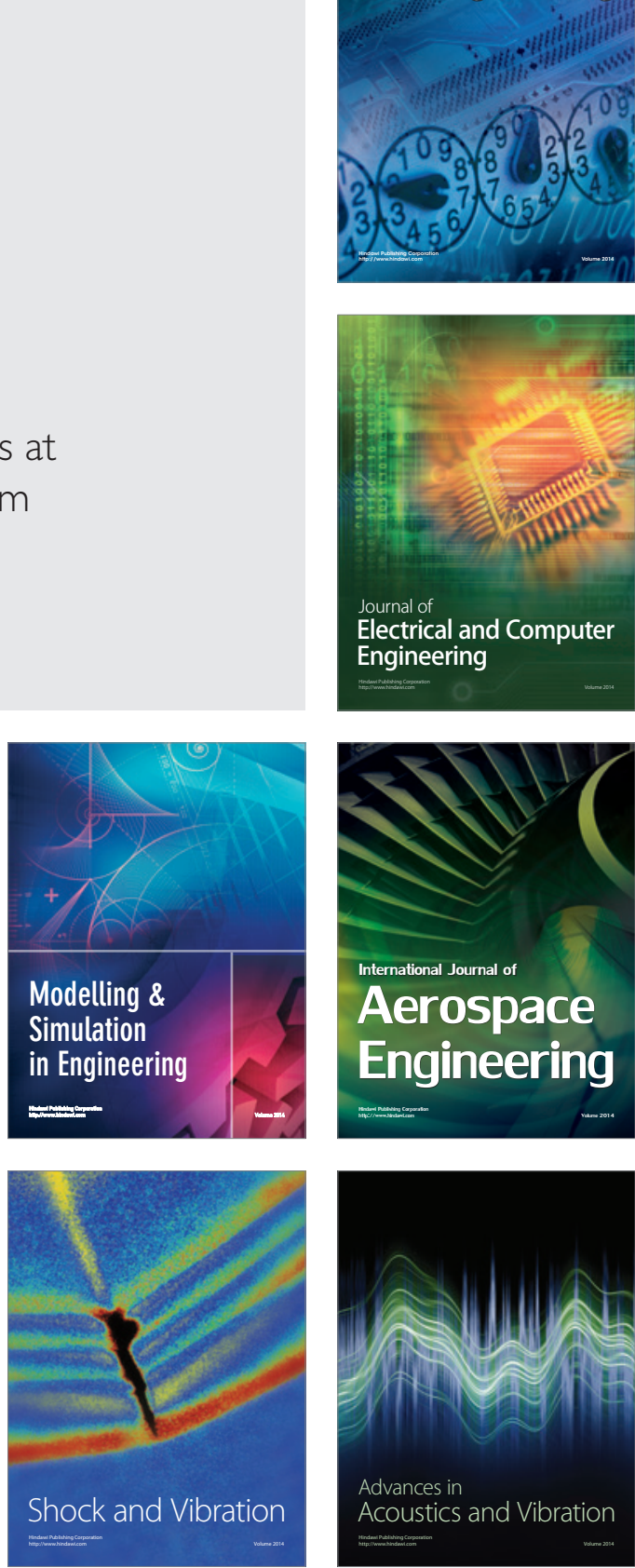